\title{
II. Meşrutiyet Dönemi Resim Sanatında Nesne ve Özne Olarak Kadın
}

\author{
İlkay Canan Okkalı $\odot$
}

Öz

Kadın teması erken dönemlerden itibaren resim sanatının temel konularından birisidir. Türk resminde ise, önce minyatürlerde ilerleyen dönemlerde ise yağlıboya resimlerde yaygın bir tema olarak kullanılır. Türk resminde kadını figür olarak kullanan ilk sanatçı ise 19. yüzyılda Osman Hamdi Bey olur. 20. yüzyıla gelindiğinde siyasi yapının değişimi ile doğrudan etkilenen toplum yapısının en belirgin sonuçları arasında kadınların kamusal alana katılması ve görünürlük kazanması yer alır. Kadınların edindikleri yeni toplumsal konum, dönemin romanlarının ve resimlerinin temaları arasına girer. Kadın artık mesire yerlerinde, deniz kenarı ya da farklı eğlence mekânlarında görselleştirilir. Kadının modernlik simgesi olarak görülmesinin bir sonucu olan bu resimler, bir nevi modernleşme sahneleri haline gelir. İnas Sanayi Nefise Mektebi ile resim alanında eğitim alan kadınlar toplumda birey olarak var olmaya çalışarak sanatçı-kadın olmalarının mücadelesini verirler. Özellikle kadın hareketinin önemli isimleri Mihri Müşfik ve Müfide Kadri gibi kadınların varlığı ile nesne olmaktan çıkarak eylemi gerçekleştiren özne konumuna yükselirler. Buna rağmen kadınların kendini ifade etme olanaklarının kısıtılığı, temsil ediliş biçimleri, erkekler ve kadınlar arasındaki sosyal, ekonomik ve toplumsal cinsiyet farklarının izlerini taşır. Bu çalışmada, Türk resim sanatında kadının yeri sorgulanırken aynı zamanda kadının resimlerde temsil edilişi ve kadın kimliğinin toplum tarafindan nasıl kurgulandığı, II. Meşrutiyet dönemi sanatçılarının yapıtları üzerinden ele alınmıştır.

\author{
Anahtar Kelimeler \\ Türk Resim Sanatı • Kadın ressam • Kadın kimliği • Mihri Müşfik • Müfide Kadri
}

\section{Women as the Object and the Subject of Art in the $2^{\text {nd }}$ Constitutional Period}

\begin{abstract}
Women theme is one of the basic subjects of painting art since the early ages. In Turkish painting, women are used as a frequent theme, first in the miniatures and then in the oil paintings in the later periods. The first artist to use a woman as the figure in Turkish painting is Osman Hamdi Bey in the $19^{\text {th }}$ century. One of the most significant effects of the political changes of the $20^{\text {th }}$ century on the societal structure is the participation and the visibility of women in the public sphere. The new social position acquired by women becomes one of themes of the novels and the paintings of the period. Women are now visualised at the recreational spots, coast or various entertainment venues. These paintings become some kind of a vision of modernisation, as women appear to be the symbol of modernity. Women receiving art education in the 'Inas Sanayi Nefise Mektebi' would struggle as women artists, while they tried to exist in the society as individuals. Especially on the account of the significant names of the women's movement, such as Mihri Müşfik and Müfide Kadri, they advanced from being an object to the status of the subject performing the action. In spite of this fact, the limitations in women's opportunities to express themselves and the forms of their representation bear the traces of the social, economic and societal differences between men and women. At this study questions the place of women in Turkish Art, while examining the representation of women in the paintings and how female identity is speculated in the society, through the works of the $2^{\text {nd }}$ Constitutional Period artists.
\end{abstract}

\section{Keywords}

Turkish Painting Art • Female painter • Female identity • Mihri Müşfik • Müfide Kadri

* Sorumlu Yazar: İlkay Canan Okkalı, (Öğr.Gör.Dr.), Trabzon Üniversitesi, Güzel Sanatlar Fakültesi, Resim Bölümü, Trabzon, Türkiye. Eposta: icanikli@gmail.com

Atıf: OKKALI, İlkay Canan, "II. Meşrutiyet Dönemi Resim Sanatında Nesne ve Özne Olarak Kadın”, Art-Sanat, 11(Ocak 2019), s. 47-70. https://doi.org/10.26650/artsanat.2019.11.0003 


\section{Giriş}

19. yüzyılın şartlarında Tanzimat ve Islahat fermanlarının getirdiği yeni düzen Osmanlı Devleti'nin toparlanmasında yetersiz kalır ve devlet, 20. yüzyılın başlarında yıkılma sürecinin içerisine girer. Dönemin aydın kesiminin öncülüğünde başlatılan değişim çabaları, II. Meşrutiyet'in (23 Temmuz 1908) ilanı ile sonuçlanır. Meşrutiyet Devri, Cumhuriyet'i hazırlayan düşünce hareketlerinin kaynaştığ fikirsel bir aydınlanma dönemi olarak önemli bir süreçtir. ${ }^{1} \mathrm{Bu}$ dönem Osmanlı toplum yapısında önemli değişimler görülür; yeni ortam hem sosyal, siyasal, kültürel, sanatsal birçok alanda yeniliklerin uygulanmasına hem de ulusal bilincin ve bireyin ön plana çıkmasına olanak tanır. ${ }^{2}$ Özellikle "vatandaşlık" kavramı üzerinden bir "kimlik" oluşumu gerçekleştirmek için çaba harcanır. ${ }^{3}$ Çağdaşlaşma girişimlerinin hayata geçmesiyle, insanların toplum içindeki konumları, kadın-erkek kimliği sorgulanmaya başlanır. Bireyin ön plana çıkmasıyla kadınlar da artık söz sahibi olmanın yollarını ararlar.

\section{Meşrutiyet Dönemi Kadının Toplumsal Konumu}

II. Meşrutiyetle, anayasa yeniden yürürlüğe girmiş, seçilmiş bir yasama organına karşı sorumlu bir bakanlar kurulu ile sultanın yetkileri kısıtlanmıştır. ${ }^{4}$ II. Meşrutiyet döneminde yapılan düzenlemelerle yeni siyasal özne "vatandaş" ile devlet arasındaki hukuksal-siyasal ilişkinin kuralları belirlenir. ${ }^{5} \mathrm{Bu}$ dönemde hukuk, ekonomi, eğitim, toplumsal yaşam değişmeye başlar ve bu modernleşmeye paralel olarak kadının konumu da değişerek kadın bir birey olarak kabul görmeye başlar. ${ }^{6}$ Dönemin kadın dergilerinde, kadınlar ve erkekler yazılar yazar, kadının hakları, kadın eşitliği, görevleri, toplumsal konumu, çalışma hayatı, evliliği, giyimi, cemiyetleşmesi gibi konular hakkında bilgiler verilerek Osmanlı kadının bilinçlenmesine katkıda bulunurlar. ${ }^{7} \mathrm{O}$ zamana dek yalnızca ev içinde anne ve eş rolleriyle sınırlanmış olan kadın, toplumsal yaşamda var olabilmek adına taleplerde bulunmaya başlar. ${ }^{8}$ Toplum tarafından kadınların eğitilmesi kabul görür ama bunun temel amacı eş ve anne olarak görevlerini daha iyi yerine getirebilmeleri içindir. Dönemin süreli yayınlarında kadın, tüm toplumsal rollerden önce anne olarak değerlendirilmeye devam eder, toplumun ilerle-

1 Halil İnalcık, "II. Meşrutiyet: Anayasa Rejimi Geliyor, Cumhuriyet Yolu Açıllyor", Doğu-Batı Düşünce Dergisi: II. Meşrutiyet 100.Yıl, S. 45, Ağustos 2008, İstanbul 2008, s. 11-16.

2 Ahmet Kamil Gören, Avni Lifij, Yapı Kredi Kültür Sanat Yayıncılık, İstanbul 2001, s. 395.

3 Füsun Üstel, "II. Meşrutiyet ve Vatandaşın İcad'ı", Modern Türkiye'de Siyasi Düşünce: Cumhuriyet'e Devreden Düşünce Mirası Tanzimat ve Meşrutiyetin Birikimi, Der. Tanıl Bora ve Murat Gültekingil, 7. basım, İletişim Yayınları, C. I, İstanbul 2006, s. 166-167.

4 Feroz Ahmad, "Cumhuriyete Doğru”, Cumhuriyet’in 75.Yılı (1923-1953), Der. B. Karaçam ve F. Aksun, 3 c., Yapı Kredi Yayınlar1: 2-5. C. I, İstanbul 1998, s. 2.

5 Füsun Üstel, a.g.m., s. 167-168.

6 Sema Uğurcan, “Tanzimat Devrinde Kadının Statüsü”, 150. Yılında Tanzimat, Haz. Hakkı Dursun Yıldız, Türk Tarih Kurumu Yayınları, Ankara 1992, s. 500-501.

7 Ümüt Akagündüz, II. Meşrutiyet Döneminde Kadın Olmak, Yeni İnsan Yayınevi, İstanbul 2015, s. 270.

8 Serpil Çakır, Osmanlı Kadın Hareketi, 5. basım, Metis Kadın Araştırmaları, İstanbul 2016, s. 59. 
mesi ve gelişmesi için bu rolün önemine dikkat çekilir. ${ }^{9}$ Bu da özünde erkek egemen, kontrolcü bir yaklaşımı gösterir. Dergilerde bir kadın mantalitesi ve ruhu irdelenmiş olsa da bu kavramların toplumsal yaşamda bıraktığı izler erkek kontrolünün dışına çıkamamıştır. ${ }^{10}$ Şöyle ki kadının yerinin evi olduğu, iyi bir kadının iyi bir anne olması gerektiği, bu annelerin gürbüz evlatlar büyütmeleri, bu evlatların vatan millet sevgisiyle yetiştirilmeleri vurgulanır. ${ }^{11}$ Erkek yazarlar tarafından kız çocuklarına yönelik hazırlanan "Kızlara Mahsus Terbiye-i Ahlâkiye ve Medeniye" ders kitapları, genç kızların bilinçlenerek gerektiğinde erkeklere destek sağlamalarını amaçlar. Bu kitaplarda genç kız, ileride çocuklarına Meşrutiyet'in değerlerini aşılayabilsin diye yeni sistemin kurum ve değerleri konusunda bilgilendirilir. ${ }^{12}$

Kadın hakları ve kadınların/kızların eğitimleri için harcanan çabanın sonucunda kız öğrencilerin resim alanında eğitim alabilmeleri adına "İnas Sanayi-i Nefise Mektebi” ilk öğrencilerini Ekim 1914'te (Halil Ethem'e göre Kasım ayında) alır. ${ }^{13}$ Okulun açılmasına zemin sağlayan etkinlik ise 7 Şubat 1914'te Darülfünun'da kadınlar için serbest konferansların düzenlenmesidir. Okulun kuruluş nedenlerinin altında "kadın eşitliği, kadın özgürlüğü, kadın hakları” gibi dönem için yeni kavramlara ilişkin düşünceler yatar. Okul ilk açıldığında 33 öğrenciye sahipken daha sonra okula yazılıp kısa bir süre çalışıp ayrılanlar, misafir öğrenci olarak devam edenler olmuştur. Mektebe ilk başvuran öğrenci, Müzdan Sait Hanım’dır (1897-1986). İkinci öğrenci Muide Esat Hanım, üçüncüsü Belkıs Mustafa Hanım (1896-1925) ve dördüncüsü ise Nazire Osman'dır. Güzin Duran (1898-1981) ve Nazlı Ecevit (1900-1985) İnas Sanayi-i Nefise Mektebi'nin verdiği ilk mezunlar arasındadır. ${ }^{14}$ Dönemin ünlü kadın sanatçıları arasında Nazmi Ziya'dan özel dersler alan ve mektebe konuk öğrenci olarak devam eden Melek Celal Sofu (1896-1976), Müfide Kadri (1889-1911), Harika Sirel Lifij (1890-1991), Vildan Gezer (1889-1974), Emine Fuad Tugay (1897-1973), Sabiha Rüştü Bozcalı (1904-1998) ve Hale Asaf (1905-1938) yer alır. ${ }^{15}$ İnas Sanayi-i Nefise Mektebi öğrencileri hem sanat ortamının oluşumuna katkıda bulunarak resme ilişkin sorunlara çözüm ararken hem de toplumda sanatçı-kadın olmalarının mücadelesini verirler.

9 Çiğdem Ülker, II. Meşrutiyet Dönemi Dergilerinde Kadın İmajı: 1908-1914, Adnan Menderes Üniversitesi, Sosyal Bilimler Enstitüsü, Tarih Anabilim Dalı, Yüksek Lisans Tezi, Aydın 2012, s. 99.

10 Ümüt Akagündüz, a.g.e., s. 85.

11 Ümüt Akagündüz, a.g.e., s. 230.

12 Füsun Üstel, a.g.m., s. 175-176.

13 Zeynep Yasa Yaman, "İnas Sanayi-i Nefise Mektebi Âlisi”, Dünden Bugüne İstanbul Ansiklopedisi, C. IV, 170, İletişim Yayınları, İstanbul 1994, s.170; Canan Beykal, "Yeni Kadın ve İnas Sanayi-i Nefise Mektebi”, Boyut, S. 16, 1983, s. 6-13.

14 Taha Toros, İlk Kadın Ressamlarımız, Akbank Yayınları, İstanbul 1988, s. 42-45; İlkay Canan Okkalı, “Güzin Duran: Eşinin Gölgesinde Bir Kadın Ressam”, Sanatın Gölgedeki Kadınları, Der. Özlem Belkıs, Duygu Kankaytsın, Ayrıntı Yayınları, İstanbul 2018, s. 448.

15 Fatma Ürekli, “Güzel Sanatlar Eğitiminde Osmanlı Hanımlarına Açılan Bir Pencere, İnas Sanayi-i Nefise Mektebi”, Tarih ve Toplum Dergisi, C. 39, S. 231, Mart, İletişim Yayınları, İstanbul 2003, s.58. 


\section{Batı Dünyasında Kadının Konumu}

Aynı dönemde Batı dünyasında da kadından beklenen roller çok farklı değildir. Temel özgürlükleri elde etmek epey sancılı olmuştur. Modernliğin kamusal deneyimlerini gerçekleştiren kişiliklerden biri flâneur, Walter Benjamin'in deyimiyle kayıtsız, avare gezgindir ve flâneur burjuva ideolojisinin bir erkek tipidir. Bir sınıf olarak burjuvazinin ekonomik ve sosyal varlık koşulları, hem sosyo-ekonomik kategoriler hem de toplumsal cinsiyet ilişkileri bakımından eşitsizlik ve farklılık üzerine kurulmuştur. ${ }^{16}$ Özel alan yani ev, kadın eşlerin, çocukların ve hizmetkârların dünyasına aittir. Erkekler ise iki dünya arasında serbestçe hareket edebilir. Burjuva kadınlar açısından kalabalıklara karışmak ahlâkî açıdan tehlikelidir. Kadın saygınlığını koruyabilmesi için evinde oturmalı, kendisini toplum içinde teşhir etmemelidir. Jules Michelet $L a$ Femme (1885-1860) adlı dergide bu durumu şu şekilde anlatır: ${ }^{17}$

"Yalnız bir kadın için ne kadar çok sıkıntı söz konusu! Örneğin, bir kadın Paris’in öteki ucundan geç saate kalıp acıksa, bir restorana girme cesaretini gösteremez. Girse olay kopar, seyirlik malzemeye dönüşür. Bütün gözler sürekli onun üzerinde sabitlenir ve kulağına kaba ve küstah sözler çalınır.”

Batı'da inşa edilen toplum yapısında kadına yer verilmeye başlanmasına rağmen kadın sanatçılar için eşitsizlikler devam eder. Griselda Pollock'ın vurguladığı gibi, Empresyonizm dönemi de dâhil olmak üzere kadın ressamlar, erkek meslektaşlarının özgürce bulundukları ve eserlerinde kullandıkları yerleri tasvir edemezler; barlar, kafeler, Kulis, Folies-Bergére Barı veya Moulin de la Galette, kadınların eserlerinde yer alamaz. Erkek sanatçılara açık olan bir dizi yer ve etkinlik kadın sanatçılara kapalıdır. ${ }^{18}$

Virginia Woolf, 20. yüzyılın başında kadın ve erkekler arasındaki eşit olmayan yaşam koşulları nedeniyle kadın yazarların literatüre geçemeyişinin kısa bir hikâyesini yazar. Kendine Ait Bir Oda kitabında Woolf, toplumsal cinsiyet olarak kadınların maruz kaldıkları eşitsizliklerden bahseder. Ev/aile yaşamı içerisinde eve hapsolan kadın kamusal alandan soyutlanır. Anne olan kadının toplumdan soyutlanması daha da artar. Erkek dışarıda yaşamına devam ederken kadın evde çocuğuna bakmalıdır. Ev işinin yapılma görevi kadına atfedilmiştir. Bu işlerin arasında kadının yaratıcı olabilmesi ve kendine vakit ayırabilmesi mümkün değildir. Virginia Woolf'un Kendine Ait Bir Oda'da dediği gibi “(...) tüm yemekler pişirilmiş, tabak çanak yıkanmış, çocuklar okula gönderilip dünyaya açılmışlardır. Geriye kalan hiçbir şey yoktur. Her şey yok olmuştur."

16 Griselda Pollock, "Modernlik ve Kadınlığın Mekânları", Sanat Cinsiyet Sanat Tarihi ve Feminist Eleştiri, Ed. Ahu Antmen, İletişim Yayınları, İstanbul 2010, s. 212-213.

17 Griselda Pollock, a.g.m., s.215; J. Michelet, La Femme, cilt XVIII, 1858-1860, Flammarion, Paris 1985, s. 413.

18 Griselda Pollock, a.g.m., s. 202.

19 Virginia Woolf, Kendine Ait Bir Oda, Afa Yayınları, İstanbul 1992, s. 134 
Kadının toplumsal cinsiyet açısından hem Batı'da hem Osmanlı'da eşitsizliği benzeşse de yine de Türk resmine konu olan kadınların ve kadın sanatçıların Batı'daki hemcinslerinden daha farklı bir modernleşme deneyimine sahip olduğunu, Meşrutiyet döneminin son evresinde hâlâ kadınların kamusal alanda nasıl giyineceğinin, nerede dolaşacağının, nasıl dolaşacağının kurallara bağlı olduğunu unutmamak gerekir. $^{20}$

\section{Meşrutiyet Dönemi Resim Sanatında Nesne Ve Özne Olarak Kadın}

Türk resim sanatında "Çallı Kuşağı" ya da "Meşrutiyet Kuşağı” olarak da anılan “1914 Kuşağ1” 1910'lardan itibaren 1930'lara kadar etkin olan ressamları ifade eder. Bu ressamlar şunlardır: İbrahim Çallı (1882-1960), Nazmi Ziya (1881-1937), Feyhaman Duran (1886-1970), Ali Sami Boyar (1880-1967), Hikmet Onat (1882-1977), Mehmet Ruhi (1880-1931), Sami Yetik (1878-1945), Avni Lifij (1886-1927), Namik İsmail (1890-1935). Bu isimle anılmalarının nedeni, 1910 yılında Paris'e eğitim için gönderilip, I. Dünya Savaşı çıkınca da yurda geri dönmüş olmalarıdır. Bu ressamların dışında aynı sanat ortamını paylaşan diğer ressamlar Ali Cemal Ben’im (1881-1939), Mehmet Ali Laga (1878-1947), Hayri Çizel (1891-1950), Diyarbakırlı Tahsin (18741931), Celal Esad Arseven (1875-1971), Bahriyeli İsmail Hakk1 (1863-1926), Üsküdarlı Cevat Bey (1875-1939), Şevket Dağ (1876-1944), İzzed Ziya (1880-1934), Mihri Müşfik (1886-1911), Celile Hikmet (1883-1956), Müfide Kadri (1889-1911) ve Belkıs Mustafa'dır (1896-1925). ${ }^{21}$

Osmanlı Devleti'nin geleneksel yapısı içerisinde kadının belirlenen rolleri 20. yüzyılın değişen yaşam koşullarında ve yaşam alanlarında farklı bir çehreye dönüşür. II. Meşrutiyet'ten sonra artan milliyetçilik akımlarıyla birlikte kadının bu özelliklerine bir de vatan sevgisi eklenir. ${ }^{22}$ Annelik vatan vazifesi olarak görülmeye başlar. $\mathrm{Bu}$ dönemde ideal Osmanlı kadını “iyi eş, iyi anne, iyi Müslüman”dır. Bu durum kadınlara artı bir yük/sorumluluk getirirken, aynı zamanda hem bir söz hakk1 verir hem de kadınların kendilerini sadece annelik üzerinden tanımlamalarına yol açar. ${ }^{23}$ Bu biçilmiş rol, kadının sosyal statüsünün artmasıyla da değișen bir durum değildir.

Kadınlar için biçilen roller ve kadının toplumsal konumu, dönemin romanlarının, dergilerinin ve resimlerinin konuları arasına girer. Türk edebiyatında ilk psikolojik

20 Ahu Antmen, "Hanımlara Mahsus, Beylere Vazife: Sanat Tarihi ve Cinsiyetli Beden”, Kimlikli Bedenler Sanat, Kimlik, Cinsiyet, Der. Ahu Antmen, Sel Yayınları, İstanbul 2014, s. 45.

21 Ahmet Kamil Gören, “Türk Resminin Doğduğu Kent: İstanbul”, Kültürler Başkenti İstanbul, Ed. F. Başar, Türk Kültürüne Hizmet Vakfi-İstanbul 2010 Avrupa Kültür Başkenti Ajansı, 29. 10. 2010, İstanbul 2010, s. 431-432.

22 Alan Duben ve Cem Behar, İstanbul Haneleri: Evlilik, Aile, Doğurganlık 1880-1940, İletişim Yayınları, İstanbul 1998, s. 236.

23 Feryal Saygılıgil, ““Anneliğin’ Osmanlı Romanında Kurgulanışı”, Toplum ve Bilim, S. 126, İletişim Yayınlar1, İstanbul 2013, s. 146. 
roman kabul edilen Eylül'ün (1901) yazarı, Mehmet Rauf, II. Meşrutiyet döneminde özellikle kadın teması üzerine yazılar yazar; Süs, Mehasin ${ }^{24}$ adında kadınlarla ilgili dergilerin yanı sıra magazin dergisi olan Gelincik ve sinema ile ilgili Sinema Yıldızı adında dört dergi yayımlar. Mehmet Rauf kadınların ilgi ve ihtiyaçlarına yönelik olarak (sosyal, siyasi, çocuk yetiştirme, iyi bir eş olma, ahlak, eğitim, kadınların terakkisi, meslek hakkı vb. konular), bazı mecmualarda ve gazetelerde yazdığı yazılarla dönemi için önemli adımlar atar. ${ }^{25}$ Dönemin kadın hareketinin öncü isimlerinden, çeşitli dergilerde yayımladığı yazılarının yanı sıra özellikle ilk dönem romanlarıyla Meşrutiyet projesinin destekçisi olmuş, Halide Edib Adıvar'ın (1882-1964) eserlerindeki kadın karakterler, doğunun ruhuyla, Batı zihniyetinin ve eğitiminin birleşmesiyle oluşur. Biyografik özellikte olan romanlardan Heyulâ (1909), Seviyye Talip (1910), Handan (1912) ve Son Eseri'ndeki (1919) kadınlar tam anlamıyla Avrupalı kadınlardır. Özellikle 1912 yılında yazdığı Handan, Türk edebiyatında kadın psikolojisini anlatan ilk eserdir. Türk kadının modernleşme serüveni üzerinde duran Halide Edib'in Handan romanında toplumsal kurallar ve kendi istekleri arasında sıkışan bir kadın karakteri tasvir edilir. Handan romanında, Batılılaşmayı hayat tarzı olarak benimseyen kadınlar yer alır. ${ }^{26}$ Halide Edib'te çoğu "iffetli anne" olan kadınların bu özelliğine ilaveten "fikir kadınlığı” öne çıkar. Halide Edib'e göre ideal kadın siyasi ve sosyal gündemi izleyen bir entelektüel olmalıdır. ${ }^{27}$

II. Meşrutiyet'le birlikte gelişen özgürlük ortamının diğer alanlar yanında sanat ortamını da olumlu anlamda etkilediği görülür. ${ }^{28} \mathrm{Bu}$ büyük değişimler resim sanatına da yansır. Kentli aydın kadınlar arasında öğretmen, memur, yazar, şair ve ressam gibi çeşitli meslek gruplarından kadınların sayısı zaman içinde artmıştır. ${ }^{29}$ Halide Edib ve

24 Eylül 1908-Kasım 1909 yılları arasında çıkarılan Mehasin, döneminde renkli fotoğraf yayımlayan ilk dergi olmuştur. Ümüt Akagündüz, a.g.e., s. 90; Mehasin, on iki sayı çıkmasına rağmen 9. sayıdan itibaren imtiyaz sahibi olarak Mehmet Rauf bu görevi üstlenmiștir. Halide Edib Adıvar'ın Mehasin'de Halide Salih ismiyle yazılmış iki yazısı bulunmaktadır. Ayrıntılı bilgi için bkz. Yasemin Ünalan, Mehmet Rauf'un Kadın Dergileri: Mehasin ve Süs (İnceleme ve Metinler), Erciyes Üniversitesi, Sosyal Bilimler Enstitüsü, Türk Dili ve Edebiyatı Anabilim Dalı, Yeni Türk Edebiyatı Bilim Dalı, Yüksek Lisans Tezi, Kayseri 2007, s. 8-19.

25 Filiz Ferhatoğlu, Mehmet Rauf'un Eserlerinde Kadın, Marmara Üniversitesi, Türkiyat Araştırmaları Enstitüsü, Türk Dili ve Edebiyatı Anabilim Dalı, Yeni Türk Edebiyatı Bilim Dalı, Doktora Tezi, İstanbul 2018, s. 2-8; Mehmet Rauf 1925 yılında Gelincik dergisinde bastığ mahkemesi tarafından 3 ay hapis cezasına çarptırılır. Mehmet Törenek, ceza almasına sebep olan resmin derginin 5. Sayısında (23 Temmuz 1340 [23 Temmuz 1924] olduğunu belirtir. Vakit gazetesine Mehmet Rauf tarafindan gönderilen bir mektupta bu resmin Fransızca La Vie Parisienne dergisinden sanat ve güzellik namına seçildiği söylenmektedir. Bkz. Mehmet Törenek, Roman ve Hikâyeleriyle Mehmet Rauf, Kitabevi Yayınları, İstanbul 1999, s. 23, 54.

26 Müzeyyen Sağlam, "Meşrutiyet Dönemi Türk Kadınının Modernleşme Serüveni: Handan”, Bartın Üniversitesi Uluslararası Edebiyat ve Toplum Sempozyumu 28-30 Nisan 2016 Bildiriler Kitabı, Bartın Üniversitesi Yayınları: 25, Bartın 2016, s. 475.

27 Sema Uğurcan, “Osmanlı-Türk Romanında Kadın Tipleri”, Edebiyatımızın Kadın Kalemleri, Haz. Nesrin Tağızade Karaca, Vadi Yayınları, Ankara 2006, s. 520.

28 Ahmet Kamil Gören, "Cumhuriyet'in İlk Y1llarında Türk Resim Sanatı-1: Günceli Yansıtan Konular”, rh+ Sanat, 2 (Kasım/Aralık), İstanbul 2002, s. 35.

29 Taha Toros, a.g.e., s.9. 
Nezihe Muhiddin gibi öncü kadınların yanı sıra bu dönemde Müfide Kadri, Mihri Müşfik, Melek Celal Sofu, Güzin Duran gibi kadın sanatçılar yetişir. ${ }^{30}$

İnas Sanayi-i Nefise Mektebi Âlisi'nde Mihri Hanım'dan sonra müdürlük yapan Ömer Adil'in Kızlar Atölyesi resmi 1914 yılında açılan okulun çalışma ortamını gösteren bir belge olması bakımından önemli bir resimdir. ${ }^{31}$ Sanatçı, Kızlar Atölyesi resminde duvarlarında resimler asılı bir atölyede resim çalışmaları yapan kızları betimlemiştir (G. 1). Resimde çağdaşlaşma yolundaki toplumun kadınlarıyla yakından ilgili bir konu ele alınmıştır. ${ }^{32}$ Kadının nesne olmaktan çıkarak eylemi gerçekleştiren özne konumuna yükselmesini ve erkekler dünyasında varoluşunu müjdeler. ${ }^{33}$

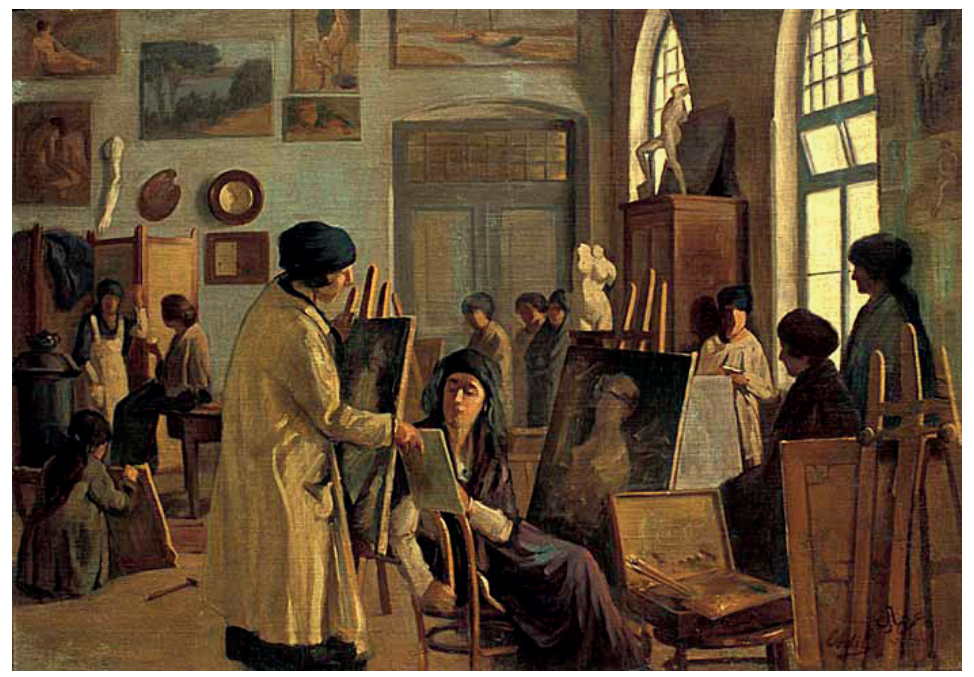

G. 1- Ömer Adil, Kızlar Atölyesi, 1919-1922, tuval üzerine yağlıboya, 81x118 cm (MSGSÜ-İRHM), (Zeynep Yasa Yaman, Kadınlar, Resimler, Öyküler Modernleşme Sürecindeki Türk Resminde “Kadın” İmgesinin Dönüşümü, Pera Müzesi Yayınları, İstanbul 2006, s.37)

Bu okulun açılması sadece devletin iradesi değil, aynı zamanda kadınların taleplerinin bir sonucudur. ${ }^{34}$ Mihri Müşfik (1886-1954) okulun kurulmasında başrol oynar.

30 Ahmet Kamil Gören,“Türkiye’de Güzel Sanatlar Okulları: 2, İnas Sanayi-i Nefise Mektebi, Kadın Ressamlar, Özel Resim Atölyesi ve Resim Kursları", Türkiyemiz Kültür ve Sanat Dergisi, S. 82, İstanbul, 1997, s. 16; Zeynep Yasa Yaman, Kadınlar, Resimler, Öyküler Modernleşme Sürecindeki Türk Resminde “Kadın” İmgesinin Dönüşümü, Pera Müzesi Yayını 9, İstanbul 2006, s. 30-31.

31 Sezer Tansuğ, Çağdaş Türk Sanatı, 8. basım, Remzi Kitabevi, İstanbul 1999, s. 139.

32 Zeynep Yasa Yaman, a.g.e., s. 36.

33 Esra Aliçavuşoğlu, “Cumhuriyet Öncesi Dönemden Günümüze Kadın Sanatçıların Kendilerine ve Kadınlara Bakışı” İ.Ü. Edebiyat Fakültesi Sanat Tarihi Yıllığı XIX, İstanbul: Sanat Tarihi Araştırma Merkezi, 19/2006, İstanbul 2007, s. 43.

34 Fatmagül Berktay, "Hayal ve Hakikat Ya Da Hayalin Hakikatine Bitmeyen Yolculuk", Hayal ve Hakikat: Türkiye'den Modern ve Çağdaş Kadın Sanatçılar, Ed. Esin Eşkinat, İstanbul Modern Sanat Müzesi, 2 İstanbul 2011, s. 33. 
Malik Aksel, Mihri Hanım'ın mektebin açılması için 1srarcı olduğunu şöyle aktarır: ${ }^{35}$ “Bir gün Mihri Hanım doğruca Maarif Nazırı Şükrü Bey’in huzuruna çıkarak:

"Muhterem Nâzır Beyefendi, memlekete Meşrutiyet'le birlikte hürriyet, müsavat, adalet, uhuvvet geldi, ama bütün bu nimetlerden sadece erkekler istifade ediyor. Kadınlar hâlâ olduğu yerde, bir adım bile ileri gitmiş değiller. Acaba bu imtiyaz nereden geliyor? Bugün her yerde müsavat ve adaletten söz ediliyor. Fakat İnas Sanâyi-i Nefise Mektebi nerede? Hep yapılanlar erkekler için!” der.

Kurulmasına ön ayak olduğu İnas Sanayi-i Nefise Mektebi'nde 1919 yılına kadar çalışan, ilk kez nü kadın modeli kız atölyesine sokan cesur kimliğiyle kendisi kadın hareketinin önemli bir parçası olan Mihri Müşfik avangard bir yaşam sürmüş olmasına rağmen, resimlerindeki kadınlar geleneksel yaşamdan da izler taşırlar. Bu dönemdeki kadın romancılar, kadının Batılılaşması tezini savunurlar. Romanlarda Batılı, ideal kadın tiplemesinin yanı sıra bir karşıt güç olarak da geleneksel kadın tiplemesini de oluştururlar. Geleneksel kadınlar her bakımdan Batılılaşma karşısındadır. Genellikle ideal kadının annesi ya da akrabası olarak (Seviyye Talib'de Macide'nin annesi, Handan'da üvey annesi) ${ }^{36}$ romanda yer edinirler ve ideal kadın portresini daha net ortaya koymaya yararlar. Mihri Müşfik, Ahmet Rıza Bey'in Annesi Naile Hanım Portresi'nde (1908-1909) eski bir Osmanlı hanımefendisini, konağın sade fakat zarif bir şekilde düzenlenmiş odasında ve kafesli penceresinin önünde betimlemiştir (G.2). Duvardaki kalem işleri, resmin sağ köşesine oturtulmuş bozalık ve sol taraftaki sahleplik ile Naile Hanım'ın oturduğu divanı kaplayan kumaşlarla ve yaslandığı yastıkta gizlenmiş diğer detaylar, o günün yaşam tarzını resmedişi dolayısıyla belge niteliği taşır. Mihri Müşfik'in, figürü elindeki tespihi ve başını örtüşü ile zarif bir Osmanlı hanımefendisi olarak kendi ev yaşantısı içinde gerçekçi yansıtma isteği dikkat çeker. Resim olgun, ailede sözü geçen, güngörmüş bir kadını duyumsatır.

35 Malik Aksel, Sanat ve Folklor, Der. Beşir Ayvazoğlu, 2. basım, Kapı Yayınları, İstanbul 2011, s. 47. 36 Sema Uğurcan, a.g.m., s. 520. 


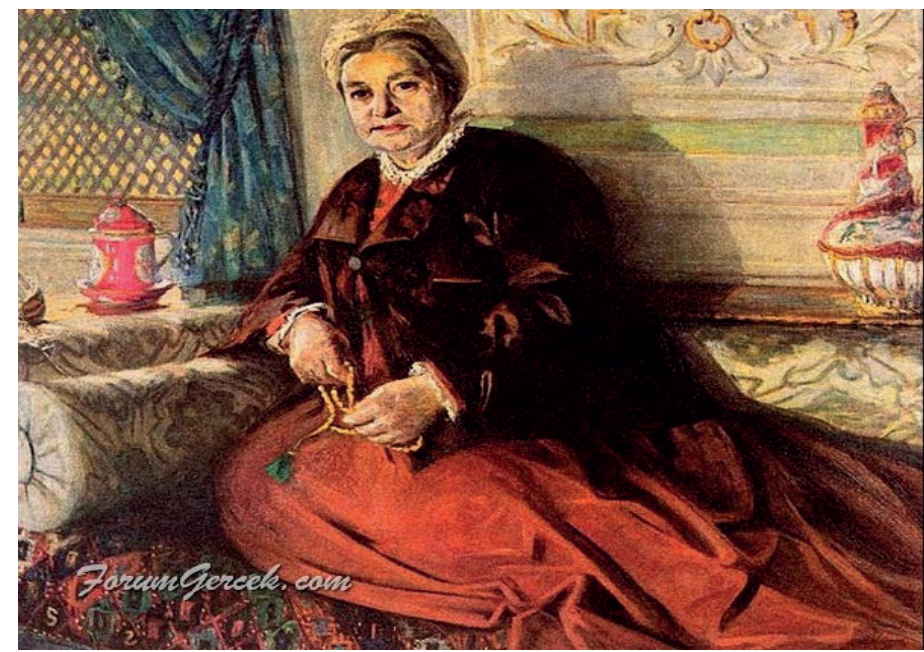

G. 2- Mihri Müşfik, Ahmet Rıza Bey'in Annesi Naile Hanım Portresi, 1908-1909, tuval üzerine yağlıboya, b.y., t.y. (Taha Toros, İlk Kadın Ressamlarımız, Akbank Yayınları, İstanbul 1988, s. 5)

Sezer Tansuğ'un belirttiği gibi zaman zaman çarşaf giyip, zaman zaman çiçekli hasır şapkaları ve zarif iskarpinleri ile alaturkalık ile alafrangalığı bir arada yaşayan Mihri Müşfik, kadın portrelerinde de bu ikilemi açıkça yansıtır. ${ }^{37}$ Mihri Hanım, dönemin aydınları ile yakın ilişkidedir ve onların resimlerini yapar. Mihri Hanım Pozitivizm'in önde gelen temsilcilerinden, Osmanlı aydını, Servet-i Fünun topluluğunun üyelerinden 1939'da milletvekili seçilen, gazeteci, Hüseyin Cahit Yalçın'ın (1875-1957) eşi Mevsume Hanım’1 da resmeder. Mevsume Hanım Portresi'nde kad1nı modern kıyafetiyle Fransız Neoklasik stilde bir koltukta oturmuş ve bacak bacak üstüne atarak poz vermiş şekilde zengin dekoratif öğelerle döşenmiş misafir odasında betimlemiştir (G.3). Mobilyaların yanı sıra, şöminenin ve kalorifer peteğinin varlığ 1 söz konusu mekânın varlıklı bir kişinin evi olduğunu gösterir.

Uçuk mavi elbisesiyle bize/izleyiciye bakan Mevsume Hanım'ın kendinden emin görünüşüyle ele alındığı yapıt, kadının toplumdaki yerini ve artan önemini gösteren bir çalışmadır. Mihri Hanım’ın kadının iç dünyası ve kadınlığına ilişkin ayrıntıların altını çizdiği resim olarak diğer resimlerinden ayrılır. Sanatçının modeli tanımanın getirdiği rahatlıkla portresini yaptığı kişiyi ustalıkla yansıtarak betimlediği bir çalışma olmuştur. Resim ayrıca II. Abdülhamid Dönemi’nde (1876-1909) gündelik hayatın parçası haline gelen yeni eşyaların katılması, yerden kalkılıp masa ve koltuklara oturulması gibi toplum düzenine katılan önemli gelişimlerin gösterimine örnektir. ${ }^{38}$

37 Sezer Tansuğ, a.g.e., s. 137; Canan Beykal, a.g.m., s. 6; Esra Aliçavuşoğlu, a.g.m., s. 46.

38 İlona Baytar, "Sultan II. Abdülhamid Dönemi Mobilyası, Karadeniz Teknik Üniversitesi Uluslararası Geleneksel Sanatlar Sempozyumu "Yazmalardaki Eı İzleri” Bildiriler (20-21 Nisan 2017), Haz. Nazmiye 


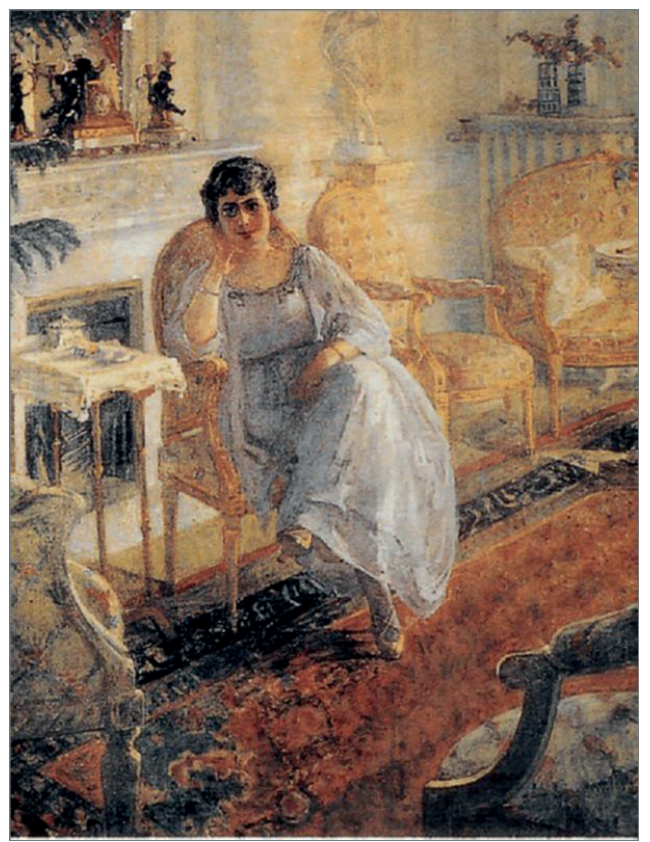

G. 3-Mihri Müşfik, Mevsume Hanım Portresi, tuval üzerine yağlıboya, 100x82 cm, (Mahinur Tuna, İlk Türk Kadın Ressam Mihri Rasim (Müşfik) Açba, As Yayınları Biyografi Dizisi:1, İstanbul 2007, s. 100)

Mihri Müşfik Hanım, yetenekli bir sanatçı ve renkli bir kişiliktir. Sanatçı, 1918'de düzenlenmeye başlayan resim sergilerinde Beyoğlu'nda ve Şişli'de resim sergisi açarak Osmanlı kadınının kültürel faaliyetlerinin gelişiminde bir ivme kazandırır. ${ }^{39}$ Mihri Müşfik, aynı zamanda çoğunluğu erkeklerden oluşan Osmanlı Ressamlar Cemiyeti'nin de üyesidir ${ }^{40}$ ve 20. yüzyılın başında Osmanlı İmparatorluğu'nda sanat üretebilme mücadelesi vermiş güçlü bir kadındır. Güzin Duran, Nazlı Ecevit, Belkıs Mustafa, Hale Asaf, Aliye Berger, Fahrelnisa Zeid gibi önemli sanatçıların arasında bulunduğu öğrencileriyle Türkiye'de kadın sanatçı geleneğini başlatır. ${ }^{41} 1927$ 'de Atlantik'i aşacak bir geminin güvertesinde New York'a doğru yola çıkar. New York'a gittikten bir yıl sonra sergi açar ve II. Dünya Savaşı yıllarında New York’ta yayınlanan dergilerin kapaklarına illüstrasyonlar yapar. ${ }^{42}$ Selim İleri, Mihri Müşfik: Ölü Bir Kelebek adlı tiyatro oyununda Mihri’yi, “sergiler bana göre değil, Paris zenginlerinin

Aydın, Nida Yıldırım, Sinan Kılıç, KTÜ Matbaası, Trabzon 2017, s. 529.

39 Serpil Çakır, a.g.e., s.100.

40 Seyfi Başkan, Osmanlı Ressamlar Cemiyeti, Çardaş Yayınları, Ankara 1994, s. 27.

41 Ayla Ödekan, “İmgenin Dönüşümü, Hayal ve Hakikat Türkiye’den Modern ve Çağdaş Kadın Sanatçılar, Ed. Esin Eşkinat, İstanbul Modern Sanat Müzesi, İstanbul 2011, s. 58.

42 Ali Asker Bal, "Mihri Müşfik İle Hale Asaf; Bedeli Ödenmiş Bohem Sanat Yaşamları”, Route Educational and Social Science Journal Volume 2 (2), April, Hatay 2015, s. 385. 
portrelerini yaparak hayatını kazanan bir kaldırım ressamı sayabilirsiniz beni" ${ }^{43}$ diye konuşturarak sergilerden ve özgün işlerden ziyade kendi yolunda olduğunu vurgular.

Müfide Kadri (1890-1912), Mihri Müşfik gibi Osmanlı Ressamlar Cemiyeti’ne üye olan ve cemiyetin sergilerine katılan diğer kadın sanatçıdır. II. Meşrutiyet döneminde kadının toplum içinde sanatsal etkinliğini artırmak yolunda bir altyapı oluşmasında Müfide Kadri ve Mihri Hanım'ın büyük etkisi olmuştur. Nezihe Muhittin'in Türk Kadını eserinden Müfide Hanım'ın Kız Lisesi'nde ilk kadın ressam olarak resim dersi verdiğini ve II. Meşrutiyet'in getirdiği yenilikçi ortam içinde olduğunu öğreniriz..4 Osmanlı kadınının o güne dek alışılmış ve onaylanmış düşünüş-davranış biçiminden farklı olarak Müfide Kadri ve Mihri Müşfik, Batılılaşma’nın zorunlu kıldığ1 "Yeni Kadın" tipine uymaya, toplumda ve çevrelerinde bunun kabullenilmesi için mücadele etmeye çalışırlar. ${ }^{45}$ Çok genç yaşta ölen Müfide Kadri için Halide Edib Adıvar bir romanını adamıştır. 1913'te Tanin gazetesinde tefrika edildikten sonra 1919 yılında basılan Son Eseri, ressam bir kadın sanatçı ile bir yazar arasında yaşanan yasak aşk ilişkisini konu olarak alır. Kitabı bizim açımızdan orijinal hâle getiren unsur, romanın ana karakterlerinden birisi olan ressam kadın tiplemesidir. Halide Edib, kitabını Müfide Kadri’ye adamasını önsözde şöyle açıklar.

"Son Eseri [ni] ithaf ettiğim Ressam Müfide, pek genç ölen ve çok sevdiğim eski bir arkadaş ve dosttu. Kahramanı bir genç kız olan bu roman, onun hayatını tasvirden ziyade ismini yaşatmak için yazılmıştı. Tekrar basmaya karar verilince sırf Müfide'nin ismi mevzu olduğu için baştan okudum. Ve hiçbir esere yapmadığım şeyi yaptım. Yani imkân dairesinde ıslaha çalıştım. Herhalde romanın kendisini yazmak için vaktiyle sarf ettiğim zamandan daha çok vakit verdim. Yine de memnun değilim. Çünkü mevzu bana ziyan edilmiş eski bir facia gibi geldi. Herhalde lisan mübalâğalarına, vak'aların fazla bariz tezatlarına imkân dairesinde dokundum. Esasından tabiî bir şey değiştirmedim.”46

Müfide Kadri Türk sanat tarihinin önemli simalarından birisidir. Kâmuran isimli roman karakteri ile Müfide Kadri'nin kişiliği büyük oranda benzerlikler taşır. $\mathrm{O}$ da, Halide Edib'in yakın çevresinde bulunan ressam ve aynı zamanda bir kadın sanatçıdır. Dahası, yazarın sevdiği ve kendisine yakın bulduğu gerçek bir insandır. ${ }^{47}$

Kısa hayatına çok şey sığdıran Müfide Kadri resimlerinde genellikle kitap okuyan, dua eden kadınları betimlemeyi sever. Kitap Okuyan Kadın adlı çalışmasında ev içi

43 Selim İleri, Mihri Müşfik: Ölü Bir Kelebek, Oğlak Yayınları, İstanbul 1998, s. 69.

44 Nezihe Muhittin ve Türk Kadını 1931: Türk Feminizminin Düşünsel Kökenleri ve Feminist Tarih Yazıcılığından Bir Örnek, Der. Ayşegül Baykan, Belma Ötüş Baskett, 2. basım, İletişim Yayınları, İstanbul 2009, s. 96.

45 Canan Beykal, a.g.m., s. 6.

46 Halide Edib Adıvar, Son Eseri, Haz. Mehmet Kalpakl1-S. Yeşim Kalpaklı, Can Yayınları, İstanbul 2008, s. 13.

47 S. Dilek Yalçın Çelik, "Halide Edip Adıvar'ın Son Eseri'nde Müfide Kadri'nin Adını Yaşatmak”, STAD Sanal Türkoloji Araştırmaları Dergisi, Temmuz 2016, İstanbul 2016, s. 18-22. 
mekânda bir divanın üzerine boylu boyunca uzanan genç kız elini başına koymuş, okuduğu kitaba odaklanmış bir şekilde betimlenir. (G.4). Uzun beyaz dantelli elbisesiyle halinden mesut gözüken genç kız resmin odak noktasını oluşturur. Eserlerinde özellikle kadın portrelerine yer veren Müfide Kadri’nin modellerinin sadece fiziksel görünüşlerine değil, ruh dünyalarına da önem verdiği göze çarpar. ${ }^{48}$ Meşrutiyet döneminin entelektüel kadınına gönderme yapan bir resimdir. Toplumsal cinsiyet kadınların eser üretme süreçlerini dünyaya ilişkin deneyimleri erkeklerinkinden farklı olduğu için etkiler. ${ }^{49}$

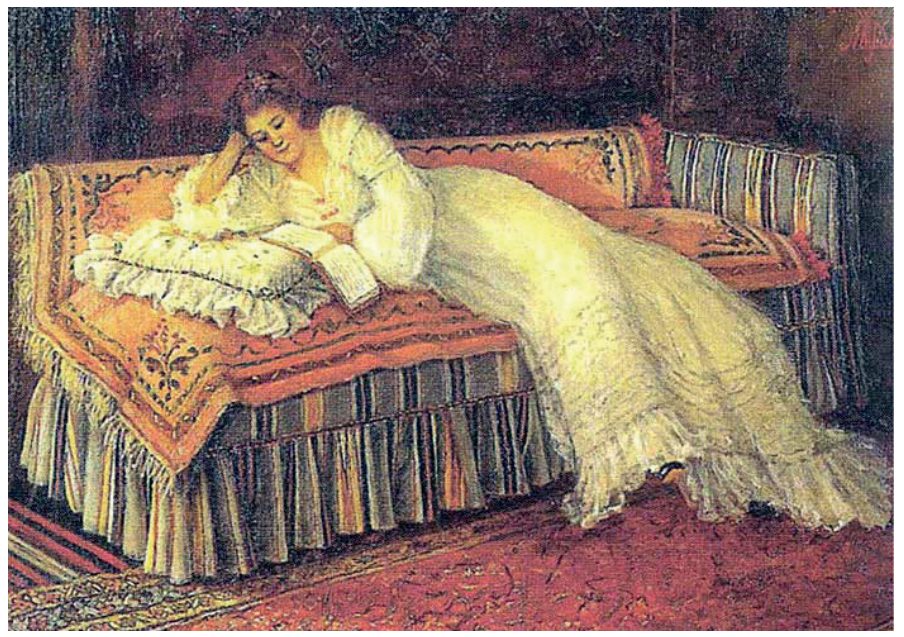

G. 4- Müfide Kadri, Kitap Okuyan Kadın, tuval üzerine yağlıboya, 40x58 cm (Özel koleksiyon), (www.istanbulkadinmuzesi.org/mufide-kadri), Erişim tarihi: 15. 04. 2013.

Mihri Müşfik ve Müfide Kadri gibi kadın sanatçılar ve öğretmenler aracıllğıyla artık kadın, tema olarak yer aldığı bu resimlerin ötesinde yavaş yavaş kendisi de özne olarak var olmaya başlar. Nitekim Müfide Kadri, Mihri Müşfik, Celile Hikmet, Belkıs Mustafa, Sabiha Bozcalı, Bedia Güleryüz, Güzin Duran, Nazlı Ecevit gibi kadın sanatçılar kendi varlıklarıyla toplumda yer edinirler.

Zeynep İnankur'a göre Osmanlı kadınının hem bir imge hem bir imza olarak, hem bir model hem bir sanatçı olarak ortaya çıkması, saray ya da yönetici elit sınıf mensubu başta olmak üzere eğitim almış olması gibi, Osmanlı toplumunda bir dizi ayrıcalıklı aşamadan geçmiş olmasına bağlıdır. Kısacası resimde görünür olabilmek, o

48 İlkay Canan Okkalı, Türk Resminde İç Mekân Resimleri (1880-1950’li Yıllar), İstanbul Üniversitesi, Sosyal Bilimler Enstitüsü, Sanat Tarihi Bilim Dalı, Yayımlanmamış Doktora Tezi, İstanbul 2014, s. 323.

49 T.P. Gouma, P. Mathews, "Sunuş: Sanat Tarihinin Feminist Eleştirisi”, Sanat Cinsiyet Sanat Tarihi ve Feminist Eleştiri, Ed. Ahu Antmen, İletişim Yayınları, İstanbul 2010, s. 41. 
dönem algılandığ şekliyle Batılı gibi görünmek koşuluyla ilişkilidir. ${ }^{50}$

Virginia Woolf kadınların, entelektüel alanda üretim yapabilmeleri için "kendilerine ait bir oda"ya ihtiyaçları olduğunu söyler. ${ }^{51}$ "Kendilerine ait bir oda"nın sahibi olamayan bilgisi ve eğitimi ile yaşadığı toplumun dışında kalmış, bu nedenle de biraz bıkkın, mutsuz ve umutsuz kadınlara Meşrutiyet sonrası resimlerde rastlanır. Ömer Adil'in Düşünen Kadın (G.5) adlı çalışması bu umutsuz durumdaki kadınlara bir örnektir. ${ }^{52}$ Sanatçı çalışmasında, sırtını izleyiciye dönmüş, uzun mavi bir elbise giyinmiş önünde açılmış zarfa dalmış bir kadını betimler. Bu umutsuzluk duygusu ve düşünceli hâl mekânın düzenlenmesinde de vurgulanır. Figürün kendisini ortama ait hissedememesi veya figürün kendini mekândan psikolojik soyutlamasıyla mekânfigür ilişkisi sağlanır.

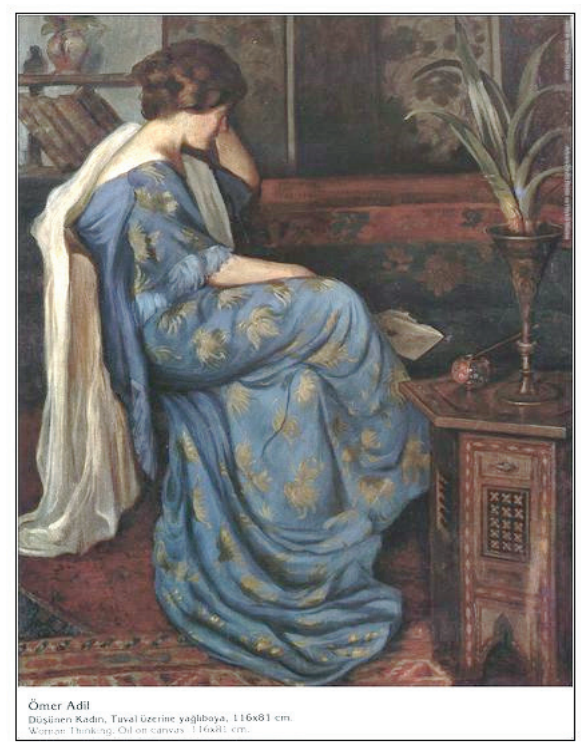

G. 5- Ömer Adil, Düşünen Kadın, tarihsiz, tuval üzerine yağlıboya, 116x81 cm (Ankara Resim ve Heykel Müzesi koleksiyonu), (Zeynep Yasa Yaman, Ankara Resim ve Heykel Müzesi, Ankara, T.C. Kültür ve Turizm Bakanlığı Yayınları, Ankara 2012, s. 149).

II. Abdülhamid devrinde sayfiye ve gezinti yerlerine gitmek modadır. Yazın Bostanc1, Yoğurtçu deresi, Fenerbahçe, Çiftehavuzlar, Göksu, Kâğıthane, Küçüksu vd. yerlerde sandal, kayık ve arabayla gezilir ve piknik yapılırd1. ${ }^{53} \mathrm{Bu}$ dönemde kimi kadınlar kapalı konak yaşamının içinde olmaya başkaldırarak, ev ve konak dışına

50 Ahu Antmen, a.g.m.,s. 45.

51 Virginia Woolf, a.g.e., s. 134.

52 İlkay Canan Okkalı, a.g.e., s. 271.

53 Zeynep Yasa Yaman, a.g.e., s. 64. 
çıarak Boğaziçi'nde gezilere katılmayı, Beyoğlu'nda alışveriş yapmayı başarır. ${ }^{54}$ Meşrutiyet'in getirdiği özgürlüklerden yararlanarak, dört duvar arasından çıkan, yaşamın doğanın güzelliklerini fark eden, keyif alan, görünür olmaktan çekinmeyen, çağa ayak uydurmaya çalışan kadınların resimlerine İzzet Ziya'nın Şemsiyeli Kadın, Deniz Kıyısında Kız, İbrahim Çallı'nın Hamakta Uzanmış Kız, Ada'da Sandal Sefası, Adada Kadınlar ve Sami Yetik' in Figürlü Peyzaj yapıtlarında rastlanır. ${ }^{55}$ Dönemin dış mekân resimlerinde özellikle gözlemlenen değişim, Osmanlı toplumunda kadınların gezi kültürünün bir parçası olan mesire yerlerindeki kadın gruplarının yerine kadınların tek başlarına, ikili olarak ve nadiren de olsa karşı cinsle temas halinde gösterilmesidir. ${ }^{56}$

İzzed Ziya (1880-1934) Paris'te Jön Türkler hareketi içinde yer alan Galip Bey’le tanışır ve onun aracılığıyla bazı sanatçılarla görüşme firsatı bulur. Yurda dönüşünde sarayda önemli bir görev olan Mabeyn Başkâtipliği'ne atanır. Türk sanatının önemli başvuru kaynakları arasında yer alan Galatasaray Sergileri'ne bakıldığında sanatçının bu etkinliklerde yine ağılıklı olarak çocuk ve kadınların bulunduğu sahillerle, kumaşlarla, güneş banyolarıyla, sandallarla, pikniklerle belirlenen doğa görünümleri ile yer aldığ 1 görülür. ${ }^{57}$ İzzed Ziya, Şemsiyeli Kadın resminde şemsiyeli beyaz uzun bir elbise giymiş bir kadını tek başına gezerken ve Deniz Klyısında Klz resminde de yine tek başına bir kadını melankolik bir şekilde denizi izlerken betimlemiştir (G. 6-7). Resimler, II. Meşrutiyet' in getirisiyle özgürleşen ve bu yüzden toplum tarafından dışlanan, umutsuz kadının yansımasıdır. Kadına yönelik reform çabaları toplum tabakasında, arzu edildiği gibi hemen sonuca ulaşmamış; Batılılaşmış üst sınıf, geleneksel yerli orta sınıf ve halk kitlelerinin aksine, giderek artan bir biçimde yabancı, yozlaşmış ve sonunda ihanet içinde görülmeye başlanmıştır. İstanbul ve Batılılaşmış kentler de gerçek yozlaşmanın ve zamanla ihanetin zemini olarak gösterilmiştir. Batılılaşmış kadın en değerli varlığını, yani "iffetini” kaybetmiş olarak algılanmaya başlanmıştır. ${ }^{58}$ Peyami Safa'nın (1889-1961) Bir Tereddüdün Romanı'nda (1933) anlatılan özgür, doğal rollerini inkâr eden, fettan, modernleşme ve Batı hayranı "yeni kadın" tipine, Sözde Kızlar (1923) romanında "tango" ismi verilir ve dini bütün mahallelerde yeni kadınlara verilen genel isme dönüşür. $\mathrm{Bu}$ günah keçisi kadınlar tam bir düzen ve gelenek yıkıcıs1, kötüye doğru gidişin yegâne sebebi olarak gösterilir. ${ }^{59} \mathrm{Bu}$ yüzden toplum dışına itilmiş hisseden Batılılaşmış kadınlar umutsuz ve bıkkın hissederler.

54 Zeynep Yasa Yaman, a.g.e., s. 68.

55 Meltem Yakın Üldes, Türk Resim Sanatında Bireyin Temsili (1880-1950'li Yıllar), İstanbul Üniversitesi, Sosyal Bilimler Enstitüsü, Sanat Tarihi Bilim Dalı, Doktora Tezi, İstanbul 2017, s. 696.

56 Ahu Antmen, a.g.m., s. 40.

57 Ahmet Kamil Gören, “İzzed Ziya’nın Ayrıksı Resimleri”, İstanbulArtNews, S. 4, Aralık, İstanbul 2013, s. 48.

58 Deniz Kandiyoti, Cariyeler, Bacılar, Yurttaşlar: Kimlikler ve Toplumsal Dönüşümler, 4. basım, Metis Yayınları, İstanbul 2013, s. 161.

59 Fatmagül Berktay, Tarihin Cinsiyeti, 3. basım, Metis Yayınları, İstanbul 2010, s. 160-161. 


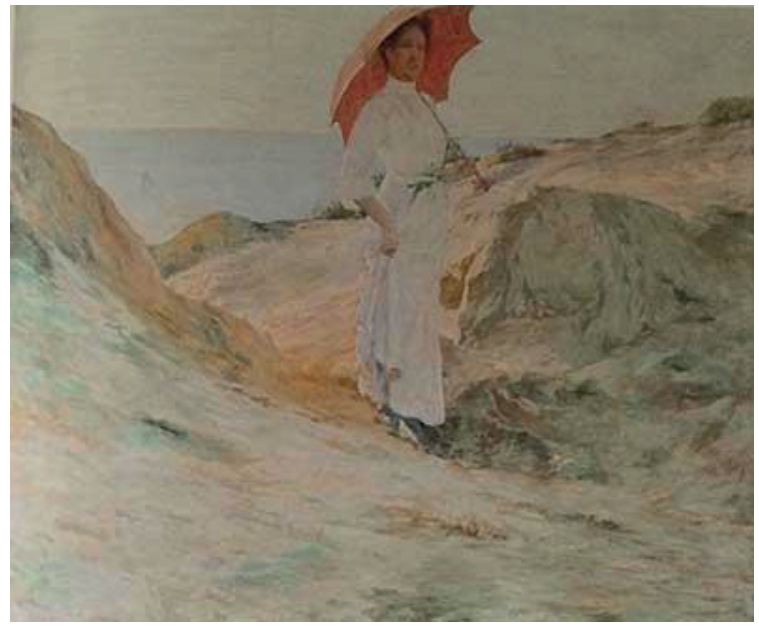

G. 6- İzzed Ziya, Şemsiyeli Kadın, 1911, tuval üzerine yağlıboya, 60x73,5 cm (Suna ve İnan Kıraç koleksiyonu), (Zeynep Yasa Yaman, Kadınlar, Resimler, Öyküler Modernleşme Sürecindeki Türk Resminde “Kadın” İmgesinin Dönüşümü, Pera Müzesi Yayınları, İstanbul 2006, s. 150)

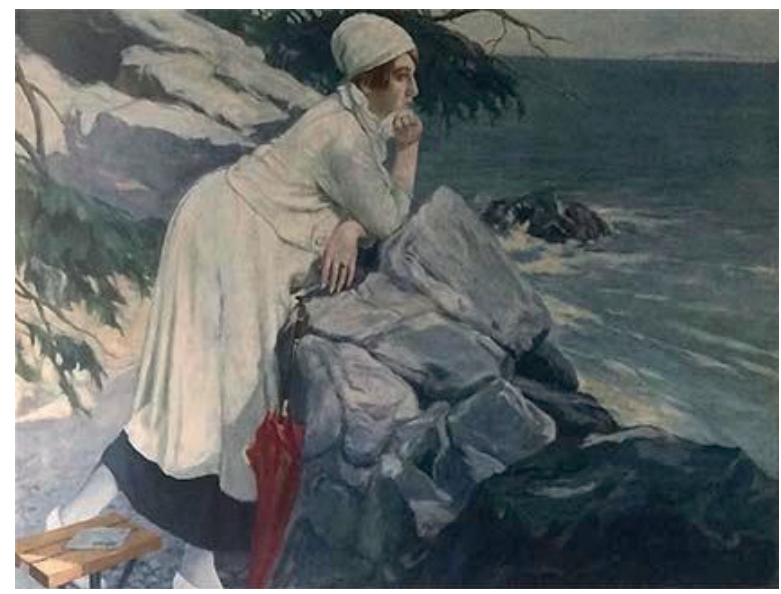

G. 7- İzzed Ziya, Deniz Kıyısında Kız, 1917, duralit üzerine yağlıboya, 45,5x63 cm (Sakıp Sabancı Müzesi koleksiyonu), (Zeynep Yasa Yaman, Kadınlar, Resimler, Öyküler

\section{Modernleşme Sürecindeki}

Türk Resminde “Kadın” İmgesinin Dönüşümü, Pera Müzesi Yayınları, İstanbul 2006, s. 114)

Romanlarda hasta ve melankolik kadınlar özellikle Meşrutiyet sonrası aşk romanları ile artar. Kadın yazarların romanlarında toplumsal baskılar ile kendi arzuları arasında kalan birey, ruhsal olarak hastalanır. Örneğin; Halide Edib'in Heyûlâ (1908) romanının başkarakteri Selma, özellikle sonbaharda derin bir melankoliye kapanan, sık sık sinir nöbetlerine tutulan bir kadındır. Yine Halide Edib'in Mev'ud Hüküm romanı 
Doktor Kasım Şinasi ile hastası Sara arasındaki ilişkiyi merkeze alır. ${ }^{60}$ Bu romanlarda özellikle kadınlar içe kapanıp, melankolikleşerek gündelik hayattan kopacak derecede hastalanırlar. ${ }^{61}$ Halide Edib, romanlarında doğayı sıkça kullanır. Özellikle bahçe, koruluk ve kameriye âşık kadının çalkantılı, gelgitli ruh durumunu temsil eden metaforlar olarak önemli mekânlardır. Doğa aynı zamanda kadının kendi kendine kalabildiği, kadınsal bir mekândır. ${ }^{62}$ Resimlerde de melankolinin verilmesinde su ve doğa önemli rol oynar.

Batı resminde 18. yüzyıldan itibaren başlı başına bir tür olarak tek başına genç k1z görüntüleri (jeune fille) yaygındır. Bir tür masumiyet simgesi olarak görülen bu genç kız resimleri 19. yüzyılda da varlığını sürdürerek yeni bir kadın kimliğinin kurgulanmakta olduğunu gösterir. ${ }^{63}$ Türk resminde de yeni kadın kimliğinin gösterimi Batı anlayışından izler taşır. Kadının modernlik simgesi olmasının bir sonucu olan bu resimlerde son moda kıyafetleri içinde kadın seyirlik bir nesnedir. Batı' da modern yaşama renk katan kadın figürünün kendi modernlik deneyimleri pek ifade bulmaz. Bu durumu tanımlamak için Janet Wolff, Baudelaire'in flâneur kavramından esinlenerek görünmez flâneuse kavramını kullanır. İzzet Ziya'nın resimlerinde kendilerini modern yaşamın içinde ifade etmeye çalışırken biraz dışlanan Wolff'un deyimiyle görünmez flâneuse kalan kadınları görmek mümkündür. ${ }^{64}$

1914 Kuşağı sanatçılarından İbrahim Çallı (1882-1960) da kadını okurken, sandal sefasında veya ikili gruplar halinde gezerken betimler. İbrahim Çallı'nın Hamakta Uzanmış Kadın resminde Boğaz manzarasına karşı hamakta kitap okuyan genç bir kız yer alır. (G. 8). Geleneksel kıyafetlerine karşın II. Meşrutiyet sonrasının yüceltilen okur-yazar kadın vurgusu resimde temsil edilir.

60 Ayşegül Utku Günaydın, Cumhuriyet Öncesi Kadın Yazarların Romanlarında Toplumsal Cinsiyet ve Kimlik Sorunsalı (1877-1923), İhsan Doğramacı Bilkent Üniversitesi, Türk Edebiyatı Bölümü, Doktora Tezi, Ankara 2012, s. 252, 257.

61 Ayşegül Utku Günaydın, a.g.e.,s. 248.

62 Ayşegül Utku Günaydın, a.g.e., s. 273.

63 Ahu Antmen, a.g.m.s. 40.

64 Ahu Antmen, a.g.m.,s. 44. 


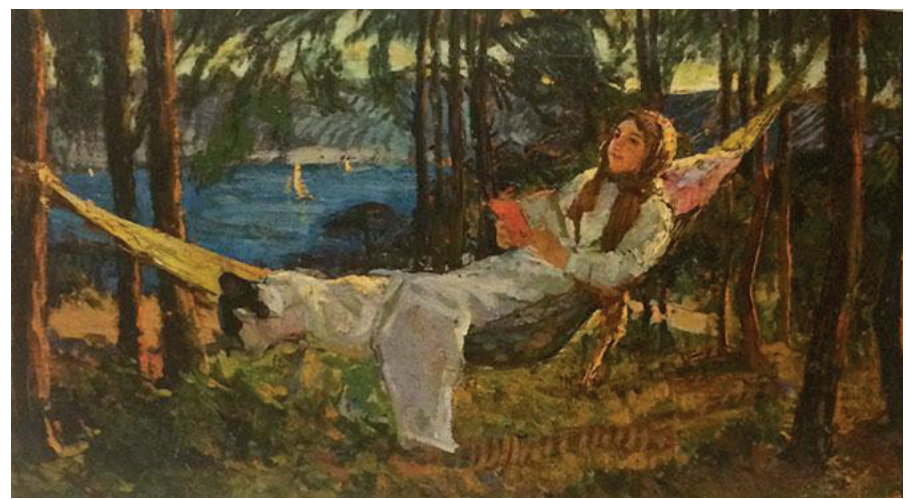

G. 8- İbrahim Çallı, Hamakta Uzanmış Kadın, 1912, tuval üzerine yağlıboya, 38x70 cm (Sakıp Sabancı Müzesi koleksiyonu), (Ed. Ferit Edgü ), Batı’ya Yolculuk: Türk Resminin 70 Yıllık

Serüveni (1860-1930), Sakıp Sabancı Müzesi Yayınları, İstanbul 2009, s. 129)

İbrahim Çallı'nın Ada'da Sandal Sefası, Adada Kadınlar resimleri Meşrutiyet'in getirdiği görece özgürlüğe sahip söz konusu yeni kadını yansıtır (G. 9-10). Tanzimat’tan sonra kadın giyiminde de Batı modası etkisi görülür. Buna ilaveten çarşafın yerini tunik elbiseler, kabarık etekler alır ve "ecnebi mağazalar"da bu elbiselerin dikimi ve satışı yapılmaya başlanır. ${ }^{65} 19$. yüzyılın sonunda Paris modasının Osmanlı dergilerinde ve onun paralelinde Osmanlı kadının üzerindeki etkisi belirginleşir, ferace ve yaşmak da ortadan kaybolur. ${ }^{66}$ Kadının giyimindeki asıl değişim Meşrutiyet'in ilanının ardından gerçekleşir. Kadınlar "yeldirme ${ }^{67}$, manto" tercih ederken çarşaf da daha alafrangalaşır. ${ }^{68}$ Kadınların kıyafetinde Tanzimat'tan Cumhuriyet'e kadar çarşaf, tayyör, palto ve başörtüsü şeklindeki değişim dikkati çeker. Mehasin, Demet, Şehbal ve Inci gibi kadın dergileri, Batı tarzında kadın modasını ve aksesuarlarını Türk kadınına tanıtmaya çalışırlar. ${ }^{69} \mathrm{Bu}$ dönemde resimlerde de değişimi izlemek mümkündür. Kıyafetlerin boyları kısalmış, başörtüsü yerini dönemin moda anlayışı olan bone şapka türüne bırakmıştır. Her iki resimde de kadınlar ikili olarak resmedilmiş, boş zamanlarını gezerek veya sandalda geçirirken gösterilmişlerdir. Erken

65 Bunlardan bazıları, Galata'da Tring, Beyoğlu'nda Bonmarşe, Mayer, Bahçekapı'da Orozdibak, Mustafa Şamlı, Macit Mehmet Karakaş, Selanik Bonmarşesi, Şismanyanko'dur. Bkz. Muhadere Taşçığlu, Türk Osmanlı Cemiyetinde Kadının Sosyal Durumu ve Kadın Kıyafetleri, Akın Matbaası, Ankara 1958, s. 22.

66 Ümüt Akagündüz, a.g.e., s. 240.

67 Yeldirme: Kadınların kırlarda serbest gezinmek için ferace ve çarşaf yerine giydikleri hafif, başa bir başörtüsü takılarak giyilen giysi. Başa bir örtü takılıp hemen sokağa çıkılabilen bir üstlük idi. Ayrıntılı bilgi için bkz. Reşat Ekrem Koçu, Türk Giyim Kuşam ve Süslenme Sözlüğü, Sümerbank Kültür Yayınları, 1969, s. 241-242. https://drive.google.com/file/d/0BxxPvlfeR2OWZ3I1ZWkzakNrU00/edit, Erişim Tarihi: 14. 12. 2018.

68 Muhadere Taşçığlu, a.g.e., s. 39-40; Meşrutiyet'in ilanından sonra İstanbul'un şık hanımları çarşaf kesimlerinde gittikçe açılan yeni modalar çıkarmışlardır. Etekleri, pelerinleri kısaltmışlar, peçeleri inceltmişler; peçe yüz üstüne atılmaya başlanarak yüz açılmış, çarşaf adeta süslü sokak kostümü haline gelmiştir. Ayrıntılı bilgi için bkz. Reşat Ekrem Koçu, a.g.e., s. 65-68.

69 Çiğdem Ülker, a.g.e., s. 85. 
dönemde özellikle kadınları günlük hayatında temsil eden 1914 Kuşağı sanatçılarının resimlerinde çalışan kadın imgesine rastlanmaması ilginçtir. Kadınlar kamusal mekânda temsil edilirken genellikle pastoral nitelikte dinlenme ve gezinti sahneleri içindedirler. Kadının kamusal görünümünün artmasıyla sahneler de çeşitlenerek mesire yerleri ya da sokak ve caddelerde yürüyenler, deniz kıyısında "banyo yapanlar", sandal gezileri vb. resme dâhil olur. ${ }^{70}$ İbrahim Çallı'nın Ada'da Sandal Sefası resmi, erken tarihli bir kamusal alan temsili olmasına rağmen kadınların kamusal alanda sandal sefalarına II. Meşrutiyet’ten önce de rastlanır. 1835 yılında İstanbul'a gelen Julia Pardoe, burada dokuz ay kalır ve o sürede kenti gezerek tanımaya çalışır. II. Mahmud'un kızı Mihrimah Sultan'ın düğün törenine tanık olan Julia Pardoe, kayıkla gezerken kayıklara kümelenmiş ışık gösterilerini izleyen birçok kadın görür ve "Kadınların sayısız beyaz yaşmakları fişeklerin ışığında dalgaların köpükleri gibi parlıyordu. Hiçbir Türk kadınının akşam sekizden sonra sokaklarda yürümesine müsaade edilmediği için, ş̧ı oyunlarını seyretmenin tek yolu sahildir" ifadelerini kullanır. ${ }^{71}$

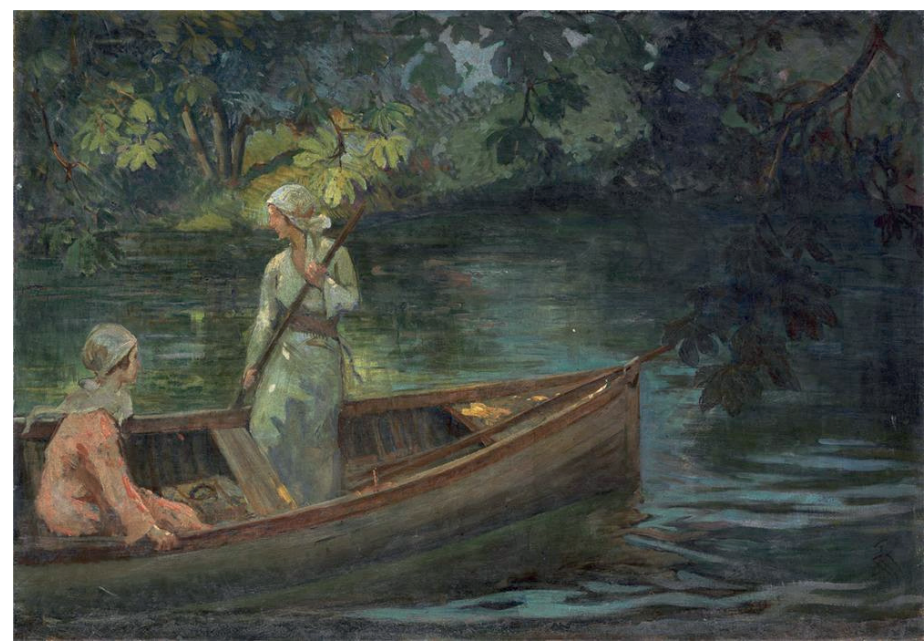

G. 9- İbrahim Çallı, Ada'da Sandal Sefası, tuval üzerine yağlıboya, 80x115 cm (Özel koleksiyon), https://www.artamonline.com/257-muzayede-degerli-tablolar-ve-antikalar/8791-ibrahim-calli1882-1960-ada-da-sandal-sefasi, Erişim tarihi: 15. 06. 2017.

70 Elif Dastarlı Dellaloğlu, Tanzimat'tan Cumhuriyet'e Türk Resminde Modernleşme: İmgeler ve Batılı Kimlik, İstanbul Üniversitesi, Sosyal Bilimler Enstitüsü, Doktora Tezi, İstanbul 2018, s. 446.

71 Julia Pardoe, Sultanlar Şehri İstanbul, Çev. M. Banu Büyükkal, Türkiye İş Bankası Kültür Yayınları, İstanbul 2010, s. 343-344. 


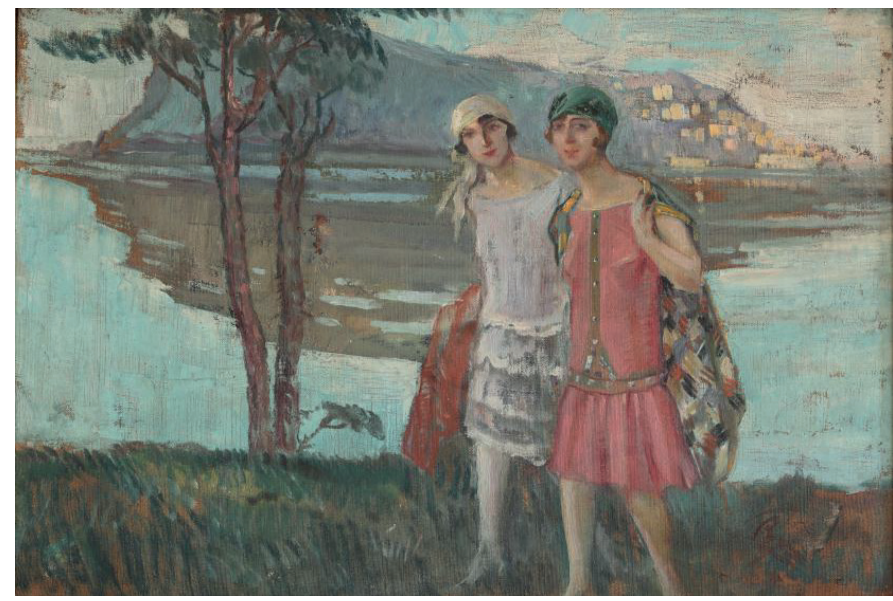

G. 10- İbrahim Çallı, Adada Kadınlar, 1917-1920 arası, tuval üzerine yağlıboya, 62x92 cm (İpek-Ahmet Merey koleksiyonu), (Meltem Yakın Üldes, Türk Resim Sanatında Bireyin Temsili (1880-1950’li Yıllar), İstanbul Üniversitesi, Sosyal Bilimler Enstitüsü, Sanat Tarihi Bilim Dal1,

Doktora Tezi, İstanbul 2017, s. 700/ Ahmet Kamil Gören Arşivi)

1912 yılında Kuleli Askeri Lisesi'nde resim hocalığı yapan, Ressamlarımız (1940 tarihli) adlı bir eseri de olan Sami Yetik (1878-1945), 1914 Kuşağı sanatçısı olarak Meşrutiyet kadınını görselleştirir. Sami Yetik Figürlü Peyzaj resminde doğa içerisinde gezen iki kadın figürü betimlemiştir (G. 11). Bu resim Meşrutiyet'in getirdiği yeniliklerin giyim kuşama yansımalarının ve kadının dışarı açılmasının izlerini taşır. Değişen moda ve kıyafet anlayışları, modernleşme sürecinde kadınların ön plana çıkmasının başlıca nedenleri arasındadır. Gerek Batı'da gerek Osmanlı toplumunda modalara uygun olarak giyinen bu kadınların esas ortak noktası ise seyirlik hallerinin ön planda olmasıdır. ${ }^{72}$ 


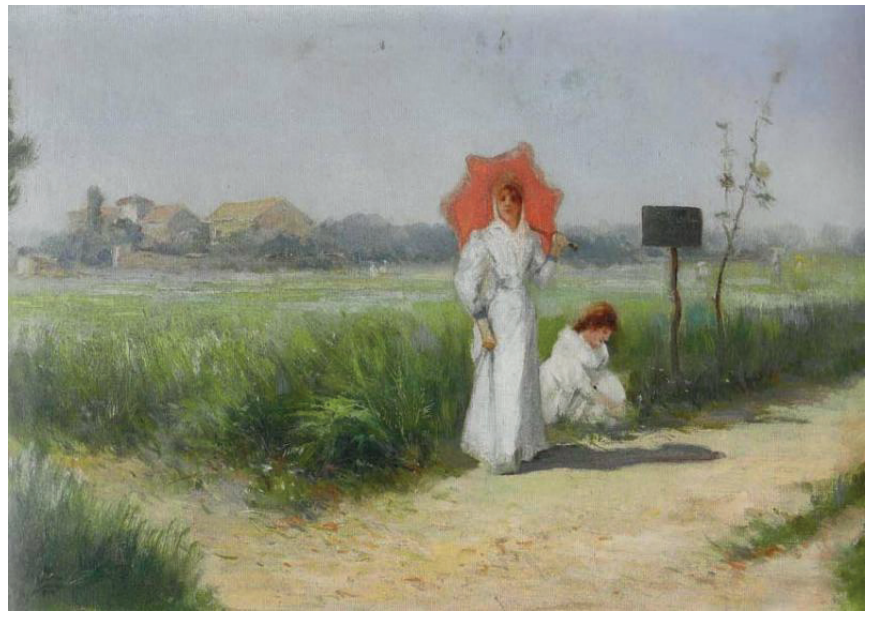

G. 11- Sami Yetik, Figürlü Peyzaj, tuval üzerine yağlıboya, 46x65 cm (Ferda-İbrahim İper koleksiyonu), (Ed. Ferit Edgü), Batı'ya Yolculuk: Türk Resminin 70 Yıllık Serüveni (18601930), Sakıp Sabancı Müzesi Yayınları, İstanbul 2009, s. 107)

Antmen'e göre geleneksel baskılara rağmen özgürleşme çabası taşıyan, özgürleşme çabasına rağmen içselleştirilmiş geleneklerin kıskacında yaşayan kimliklerin yeniden inşa edildiği bir sürecin resimleri olarak bu kadın görüntüleri, bireysel bir estetik kaygı ya da hayal âleminin ötesinde, kültürel bir kimlik arayışının ürünleridir. ${ }^{73}$

Meşrutiyet’ten itibaren kadının bir birey olarak algılanması yönündeki düşünsel gelişimin başlangıç aşamasını resimlerde görmeye başlamamıza rağmen II. Meşrutiyet döneminin resme konu olan kadınları, genellikle erkeklerin gözlemlerine dayanır, bu resimler ressamın sanat anlayışı, toplumsal görüşü ve kadını nasıl gördüğünün yansımalarıdır. Resimlerde görünen kadınlar Osmanlı'nın değişen dünyasının simgeleri olmuşken çok az resimde onların imzası vardır. Aynı durum kadın yazarlarda da vardır. Yine kendisi bir kadın olmasına rağmen Halide Edib romanlarında kadın karakterleri erkek bakışıyla kurgular.

\section{Sonuç}

Kadın imgesinin 19. yüzyıldan itibaren toplumsal modernleşme dinamikleriyle özdeşleştirilmesi, Osmanlı ressamlarının Batı sanatıyla kurmaya başladığı bağın temelini de oluşturur. Özellikle 1914 Kuşağı'nın eğitim aldığı Paris, Batı sanatının merkezi konumundadır ve kadın Paris'te bir tür modernlik simgesi konumundadır. Özellikle 1914 Kuşağı/Meşrutiyet Kuşağı sanatçılarının resimlerinde Paris'te aldıkları eğitimin bir sonucu olarak kadın, modernin temsili olarak karşımıza çıkar. 
II. Meşrutiyet dönemi edebiyatında, kadın dergilerinde ve resimlerinde ideal kadın vurgulanır, bu ideal kadın eğitimli olmak zorundadır. Kitap Okuyan Kadın resimleri bu eğitimli kadını vurgular. Kendilerine ait boş zamanı olan şanslı kadınlar tek başına resmedilir ve bu çalışmalar kadının bireysellik çabasına katkıda bulunur. Kadınların resim gibi sanat dallarıyla ilgilendiklerini gösteren yapıtlarla birlikte, resimde sanatçı-kadın imgesi ortaya çıkar. Kadınlar artık kamusal yaşamda da yerleri olması için uğraş verirler; henüz erkeklerle birlikte olmasa da ikili kadın grupları ile dışarıda sosyalleşebilen kadın resimleri bu dönemde görülür. Eğitimli, Batılılaşmış ama toplumla arasına mesafe girmiş, umutsuz kadınların izlerine bu dönem resimlerinde rastlarız. Dönemin aydın, kendine güvenen kadınları ve Osmanlı'nın kalburüstü ailelerinin kadın görselleri Mihri Müşfik'in resimlerinde yer alırlar.

II. Meşrutiyet döneminde kadının toplum içinde sanatsal etkinliğini artırma yolunda bir alt yapı oluşturmada Müfide Kadri ve Mihri Hanım'ın büyük etkisi olmuştur. Kurulmasına ön ayak olduğu İnas Sanayi-i Nefise Mektebi'nde 1919 yılına kadar hocalık yapan, Beyoğlu ve Şişli'de sergilere katılan, Türk kadın ressamlarının yetişmesinde büyük emeği olan Mihri Müşfik ve Kız Lisesi’nde resim öğretmenliği yapan, sergilere katılan, Müfide Kadri Osmanlı kadınının o güne dek alışılmış ve onaylanmış düşünüş-davranış biçiminden farklı olarak Batılılaşma'nın zorunlu kıld1ğ1 "Yeni Kadın"ın örnek temsilcileridir. Buna rağmen, tarihsel anlatılara bakıldığında kadınları sanatçı olarak değil de kadın sanatçı olarak tanımlama eğilimi göze çarpar.

Kadın ister annelik rolünde betimlensin, ister dört duvar arasından çıkıp sosyal hayat içinde gösterilsin, ister entelektüel yönü vurgulansın resimde tema olarak yer alırken, II. Meşrutiyet döneminde toplumsal ve sanat konularında aktif olan, birçok kadın sanatçı yetiştiren, erkek ressamların çoğunlukta olduğu Osmanlı Ressamlar Cemiyetinde yer alan, kadın hareketinin önemli isimleri Mihri Müşfik ve Müfide Kadri gibi kadınların varlığı ile nesne olmaktan çıkarak eylemi gerçekleştiren özne konumuna yükselir. Bu yükselmeye rağmen Meşrutiyet döneminden Cumhuriyet dönemine uzanan süreçte kadınların kendini ifade etme olanaklarının kısıtlılığı, temsil ediliş biçimleri erkekler ve kadınlar arasındaki sosyal, ekonomik ve toplumsal cinsiyet farkının izlerini taşır.

\section{Kaynakça/References}

ADIVAR, Halide Edib, Son Eseri, Haz. Mehmet Kalpaklı-S. Yeşim Kalpaklı, Can Yayınları, İstanbul 2008.

AHMAD, Feroz, “Cumhuriyete Doğru”, Cumhuriyet'in 75. Yılı (1923-1953), Der. B. Karaçam ve F. Aksun, Yapı Kredi Yayınları: 2-5. C. I, İstanbul 1998.

AKAGÜNDÜZ, Ümüt, II. Meşrutiyet Döneminde Kadın Olmak, Yeni İnsan Yayınevi, İstanbul 2015.

AKSEL, Malik, Sanat ve Folklor, Der. Beşir Ayvazoğlu, 2. basım, Kapı Yayınları, İstanbul 2011. 
ALİÇAVUŞOĞLU, Esra, “Cumhuriyet Öncesi Dönemden Günümüze Kadın Sanatçıların Kendilerine ve Kadınlara Bakışı” İ.Ü. Edebiyat Fakültesi Sanat Tarihi Yıllığı XIX, Sanat Tarihi Araştırma Merkezi, 19/2006, İstanbul 2007, s. 41-72.

ANTMEN, Ahu, "Hanımlara Mahsus, Beylere Vazife: Sanat Tarihi ve Cinsiyetli Beden”, Kimlikli Bedenler Sanat, Kimlik, Cinsiyet, Der. Ahu Antmen, Sel Yayınları, İstanbul 2014, s. 33-54.

BAL, Ali Asker, "Mihri Müşfik İle Hale Asaf; Bedeli Ödenmiş Bohem Sanat Yaşamları", Route Educational and Social Science Journal Volume 2 (2), April 2015, s. 378-388.

BAŞKAN, Seyfi, Osmanlı Ressamlar Cemiyeti, Çardaş Yayınları, Ankara 1994.

BAYTAR, İlona, "Sultan II. Abdülhamid Dönemi Mobilyası, Karadeniz Teknik Üniversitesi Uluslararası Geleneksel Sanatlar Sempozyumu "Yazmalardaki EI İzleri” Bildiriler (20-21 Nisan 2017), Haz. Nazmiye Aydın, Nida Yıldırım, Sinan Kılıç, KTÜ Matbaası, Trabzon 2017, s. 527-534.

BERKTAY, Fatmagül, "Hayal ve Hakikat Ya Da Hayalin Hakikatine Bitmeyen Yolculuk", Hayal ve Hakikat: Türkiye'den Modern ve Çağdaş Kadın Sanatçılar, Ed. Esin Eşkinat, İstanbul Modern Sanat Müzesi, 2, İstanbul 2011, s. 27-41.

BERKTAY, Fatmagül, Tarihin Cinsiyeti, 3. basım, Metis Yayınları, İstanbul 2010.

BEYKAL, Canan, "Yeni Kadın ve İnas Sanayi-i Nefise Mektebi”, Boyut, S. 16, 1983, s. 6-13.

ÇAKIR, Serpil, Osmanlı Kadın Hareketi, 5. basım, Metis Kadın Araştırmaları, İstanbul 2016.

ÇELİK, S. Dilek Yalçın, “Halide Edip Adıvar'ın Son Eseri'nde Müfide Kadri'nin Adını Yaşatmak”, STAD Sanal Türkoloji Araştırmaları Dergisi, Temmuz 2016, İstanbul 2016, s.18-22.

DELLALOĞLU, Elif Dastarlı, Tanzimat'tan Cumhuriyet'e Türk Resminde Modernleşme: İmgeler ve Batılı Kimlik, İstanbul Üniversitesi, Sosyal Bilimler Enstitüsü, Doktora Tezi, İstanbul 2018.

DUBEN Alan, BEHAR, Cem, İstanbul Haneleri: Evlilik, Aile, Doğurganlık 1880-1940, İletişim Yayınları, İstanbul 1998.

FERHATOĞLU, Filiz, Mehmet Rauf'un Eserlerinde Kadın, Marmara Üniversitesi, Türkiyat Araştırmaları Enstitüsü, Türk Dili ve Edebiyatı Anabilim Dalı, Yeni Türk Edebiyatı Bilim Dalı, Doktora Tezi, İstanbul 2018.

GOUMA, T. P. P. Mathews, "Sunuş: Sanat Tarihinin Feminist Eleştirisi”, Sanat Cinsiyet Sanat Tarihi ve Feminist Eleştiri, Ed. Ahu Antmen, İletişim Yayınları, İstanbul 2010, s. 13-117.

GÖREN, Ahmet Kamil, Avni Lifij, Yapı Kredi Kültür Sanat Yayıncılık, İstanbul 2001.

GÖREN, Ahmet Kamil, “Cumhuriyet'in İlk Yıllarında Türk Resim Sanat1-1: Günceli Yansıtan Konular”, rh+ Sanat, S. 2, Kasım/Aralık, İstanbul 2002, s. 32-39.

GÖREN, Ahmet Kamil, “İzzed Ziya’nın Ayrıksı Resimleri”, İstanbulArtNews, S. 4, Aralık, İstanbul 2013, s. 48.

GÖREN, Ahmet Kamil, “Türk Resminin Doğduğu Kent: İstanbul”, Kültürler Başkenti İstanbul, Ed. F. Başar, Türk Kültürüne Hizmet Vakfi-İstanbul 2010 Avrupa Kültür Başkenti Ajansı, 29. 10. 2010, İstanbul 2010, s. 430-441.

GÖREN, Ahmet Kamil, “Türkiye'de Güzel Sanatlar Okulları: 2, İnas Sanayi-i Nefise Mektebi, Kadın Ressamlar, Özel Resim Atölyesi ve Resim Kursları”, Türkiyemiz Kültür ve Sanat Dergisi, S. 82, İstanbul 1997, s. 12-17.

GÜNAYDIN, Ayşegül Utku, Cumhuriyet Öncesi Kadın Yazarların Romanlarında Toplumsal Cinsiyet Ve Kimlik Sorunsalı (1877-1923), İhsan Doğramacı Bilkent Üniversitesi, Türk Edebiyatı Bölümü, Doktora Tezi, Ankara 2012. 
İLERİ, Selim, Mihri Müşfik: Ölü Bir Kelebek, Oğlak Yayınları, İstanbul 1998.

İNALCIK, Halil, “II. Meşrutiyet: Anayasa Rejimi Geliyor, Cumhuriyet Yolu Açılıyor”, Doğu-Batı

Düşünce Dergisi: II. Meşrutiyet 100.Yıl, S. 45, Ağustos 2008, İstanbul 2008, s. 11-16.

KANDIYYOTI, Deniz, Cariyeler, Bacılar, Yurttaşlar: Kimlikler ve Toplumsal Dönüşümler, 4. basım, Metis Yayınları, İstanbul 2013.

KOÇU, Reşat Ekrem, Türk Giyim Kuşam ve Süslenme Sözlüğü, Sümerbank Kültür Yayınları, İstanbul 1969, (https://drive.google.com/file/d/0BxxPvlfeR2OWZ3I1ZWkzakNrU00/edit, Erişim Tarihi: 14. 12. 2018.

MICHELET, J., La Femme, cilt XVIII, 1858-1860, Flammarion, Paris 1985.

Nezihe Muhittin ve Türk Kadını 1931: Türk Feminizminin Düşünsel Kökenleri ve Feminist Tarih Yazıcılığından Bir Örnek, Der. Ayşegül Baykan, Belma Ötüş Baskett, 2. basım, İletişim Yayınları, İstanbul 2009.

OKKALI, İlkay Canan, “Güzin Duran: Eşinin Gölgesinde Bir Kadın Ressam”, Sanatın Gölgedeki Kadınları, Der. Özlem Belkıs, Duygu Kankaytsın, Ayrıntı Yayınları, İstanbul 2018, s. 444-456.

OKKALI, İlkay Canan, Türk Resminde İç Mekân Resimleri (1880-1950'li Y1llar), İstanbul Üniversitesi, Sosyal Bilimler Enstitüsü, Sanat Tarihi Bilim Dalı, Doktora Tezi, İstanbul 2014.

ÖDEKAN, Ayla, “İmgenin Dönüşümü, Hayal ve Hakikat Türkiye’den Modern ve Çağdaş Kadın Sanatçılar, Ed. Esin Eşkinat, İstanbul Modern Sanat Müzesi, İstanbul 2011, s. 56-65.

PARDOE, Julia, Sultanlar Şehri İstanbul, Çev. M. Banu Büyükkal, Türkiye İş Bankası Kültür Yayınları, İstanbul 2010.

POLLOCK, Griselda, "Modernlik ve Kadınlığın Mekânları”, Sanat Cinsiyet Sanat Tarihi ve Feminist Eleştiri, Ed. Ahu Antmen, İletişim Yayınları, İstanbul 2010, s. 187-247.

SAĞLAM, Müzeyyen, "Meşrutiyet Dönemi Türk Kadınının Modernleşme Serüveni: Handan", Bartın Üniversitesi Uluslararası Edebiyat ve Toplum Sempozyumu 28-30 Nisan 2016 Bildiriler Kitabı, Bartın Üniversitesi Yayınları: 25, Bartın 2016, s. 475-480.

SAYGILIGİL, Feryal, “'Anneliğin’ Osmanlı Romanında Kurgulanışı”, Toplum ve Bilim, S.126, İletişim Yayınları, İstanbul 2013, s. 144-161.

TANSUĞ, Sezer, Çağdaş Türk Sanatı, 8. basım, Remzi Kitabevi, İstanbul 1999.

TAŞÇIOĞLU, Muhadere, Türk Osmanlı Cemiyetinde Kadının Sosyal Durumu ve Kadın Kıyafetleri, Akın Matbaası, Ankara 1958.

TOROS, Taha, İlk Kadın Ressamlarımız, Akbank Yayınları, İstanbul 1988, s. $42-45$

TÖRENEK, Mehmet, Roman ve Hikâyeleriyle Mehmet Rauf, Kitabevi Yayınları, İstanbul 1999.

TUNA, Mahinur, İlk Türk Kadın Ressam Mihri Rasim (Müşfik) Açba, As Yayınları Biyografi Dizisi:1, İstanbul 2007.

UĞURCAN, Sema, “Tanzimat Devrinde Kadının Statüsü”, 150. Yılında Tanzimat, Haz. Hakkı Dursun Y1ldı, Türk Tarih Kurumu Yayınları, Ankara 1992, s. 497-510.

UĞURCAN, Sema, “Osmanlı-Türk Romanında Kadın Tipleri”, Edebiyatımızın Kadın Kalemleri, Haz. Nesrin Tağızade Karaca, Vadi Yayınları, Ankara 2006, s. 519-528.

ÜLDES, Meltem Yakın, Türk Resim Sanatında Bireyin Temsili (1880-1950’li Yıllar), İstanbul Üniversitesi, Sosyal Bilimler Enstitüsü, Sanat Tarihi Bilim Dalı, Doktora Tezi, İstanbul 2017.

ÜLKER, Çiğdem, II. Meşrutiyet Dönemi Dergilerinde Kadın İmajı: 1908-1914, Adnan Menderes Üniversitesi, Sosyal Bilimler Enstitüsü, Tarih Anabilim Dalı, Yüksek Lisans Tezi, Aydın 2012. 
ÜNALAN, Yasemin, Mehmet Rauf'un Kadın Dergileri: Mehasin ve Süs (İnceleme ve Metinler), Erciyes Üniversitesi, Sosyal Bilimler Enstitüsü, Türk Dili ve Edebiyatı Anabilim Dalı, Yeni Türk Edebiyatı Bilim Dalı, Yüksek Lisans Tezi, Kayseri 2007.

ÜREKLİ, Fatma, "Güzel Sanatlar Eğitiminde Osmanlı Hanımlarına Açılan Bir Pencere, İnas Sanayi-i Nefise Mektebi”, Tarih ve Toplum Dergisi, C. 39, S. 231, Mart, İletişim Yayınları, İstanbul 2003, s. 50-60.

ÜSTEL, Füsun, “II. Meşrutiyet ve Vatandaşın İcad'ı”, Modern Türkiye'de Siyasi Düşünce: Cumhuriyet'e Devreden Düşünce Mirası Tanzimat ve Meşrutiyetin Birikimi, Der. Tanıl Bora ve Murat Gültekingil, 7. basım, İletişim Yayınları, C. I, İstanbul 2006, s. 1-179.

YAMAN, Zeynep Yasa, “İnas Sanayi-i Nefise Mektebi Âlisi”, Dünden Bugüne İstanbul Ansiklopedisi, C. IV, 170, İletişim Yayınları, İstanbul 1994, s. 170-171.

YAMAN, Zeynep Yasa, Kadınlar, Resimler, Öyküler Modernleşme Sürecindeki Türk Resminde “Kadın” İmgesinin Dönüşümü, Pera Müzesi Yayını 9, İstanbul 2006.

WOOLF, Virginia, Kendine Ait Bir Oda, Afa Yayınları, İstanbul 1992. 